\title{
UPAYA GURU DALAM MENINGKATKAN PERUBAHAN PERILAKU SISWA DALAM KETERAMPILAN MENULIS TEKS BERITA PADA SISWA KELAS XII IPS1 DI SMA NEGERI 1 PONTIANAK SETELAH MENGIKUTI PEMBELAJARAN MENGGUNAKAN METODE PARTISIPATORI DENGAN TEKNIK ATTL
}

\author{
WISNU UTAMIARTI \\ Guru SMA Negeri 1 Pontianak \\ E-mail : Wisnuutamiarti17@gmail.com
}

\begin{abstract}
ABSTRAK
Keterampilan menulis harus mendapat perhatian yang lebih karena keterampilan yang paling sulit dibandingkan keterampilan yang lain. Menulis tidak hanya menuangkan ide atau gagasan yang ada tetapi melibatkan serangkaian pengetahuan dan keterampilan lain untuk dapat menjadikan tulisan itu enak dibaca. Kegiatan tulis menulis bertujuan untuk mengungkap faktafakta, perasaan, sikap, isi pikiran secara jelas dan efektif kepada pembacanya. Keterampilan menulis tidak datang secara otomatis, tetapi harus melalui latihan dan praktik. Berdasarkan hasil analisis data pada penelitian siklus I dan siklus II diketahui adanya peningkatan ketuntasan yang diperoleh siswa dalam pembelajaran menulis teks berita. Hasil ketuntasan tes pada siklus I sebesar 36,84\% dengan nilai rata-rata sebesar 70,24 dalam kategori baik. Pada siklus II, ketuntasan siswa mencapai 97,36\% dengan nilai rata-rata yang dicapai sebesar 84,81 dan termasuk dalam kategori baik. Terjadi peningkatan dari siklus I sebesar 60,52\%. Pembelajaran menulis teks berita menggunakan metode pastisipatori dengan teknik ATTL mampu mengubah perilaku siswa Kelas XII IPS1 SMA Negeri 1 Pontianak. Perubahan tersebut seperti siswa yang semula kurang siap, kurang bersemangat, dan kurang aktif dalam mengikuti pembelajaran menjadi siap, bersemangat, senang, dan menikmati pembelajaran. Siswa juga tampak lebih aktif dan tidak malu bertanya pada narasumber dan ketika menemui kesulitan.
\end{abstract}

Kata kunci: Menulis teks berita, metode partisipatori, teknik ATTL.

\section{PENDAHULUAN}

Menulis adalah suatu kegiatan menuangkan suatu ide dalam bentuk tulisan. Menulis merupakan suatu keterampilan berbahasa yang digunakan untuk berkomunikasi secara tidak langsung. Keterampilan menulis merupakan salah satu keterampilan berbahasa yang paling kompleks. Keterampilan menulis mengharuskan penguasaan berbagai unsur kebahasaan. Kegiatan menulis juga membutuhkan konsentrasi yang tinggi. Keterampilan menulis sebagai salah satu dari keterampilan berbahasa mempunyai peranan penting dalam kehidupan.

Kegiatan menulis menjadikan seseorang mampu mengungkapkan ide dan pikiran. Kompetensi mata pelajaran Bahasa dan Sastra Indonesia untuk bidang studi bahasa terdiri atas empat aspek, yaitu keterampilan mendengarkan, keterampilan berbicara, keterampilan membaca, dan keterampilan menulis. Keempat keterampilan tersebut pada dasarnya merupakan satu kesatuan, merupakan catur tunggal. Dawson, [et al] (1963:27, dalam Tarigan, 1982:1). Keterampilan menyimak dan keterampilan membaca termasuk keterampilan yang bersifat reseptif, sedangkan keterampilan menulis dan keterampilan berbicara merupakan keterampilan yang bersifat produktif.

Keterampilan menulis penting bagi siswa, akan tetapi pada kenyataannya disekolah kurang mendapat perhatian dan sering kali diremehkan oleh siswa maupun guru. Menurut mereka, setiap orang pasti bisa menulis dan keterampilan menulis tidak perlu diberikan dengan pembelajaran secara khusus. Oleh karena itu, pembelajaran menulis belum terlaksana dengan baik. Ketika pembelajaran menulis berlangsung siswa kurang bersemangat, kurang berkonsentrasi, dan tidak antusias. Hal ini disebabkan oleh anggapan siswa yang merasa kurang 
mendapat manfaat dari pembelajaran menulis dan menganggap mudah pelajaran Bahasa Indonesia (Wagiran dan Mukh Doyin. 2005: 101).

Guru juga mengalami kesulitan dalam menerapkan menulis yang baik karena siswa tidak antusias menerima pelajaran dan sulit untuk diajak serius. Mereka lebih memilih berbicara dengan teman daripada mendengarkan penjelasan guru. Selain itu, metode dan teknik yang digunakan guru kurang tepat sehingga pada akhirnya siswa tidak tertarik dengan pembelajaran. Proses pembelajaran menulis teks berita dianggap berhasil jika kompetensi dasar yang disamPelajaran Bahasa Indonesiakan tercaPelajaran Bahasa Indonesia.

Hal tersebut dapat terlihat dari pencaPelajaran Bahasa Indonesiaan indikator yang maksimal. Indikator dalam pembelajaran menulis yang harus dicaPelajaran Bahasa Indonesia meliputi: Siswa mampu menulis teks berita dengan unsur berita lengkap, , Siswa mampu menulis teks berita dengan memperhatikan keruntutan pemaparan, penggunaan kalimat, penggunakan kosakata, kemenarikan judul, dan penggunaan ejaan, dan Siswa mampu menulis teks berita secara singkat, padat, dan jelas. Indikator pertama siswa mampu menulis teks berita dengan unsur berita lengkap.

Hal tersebut merupakan dasar bagi siswa untuk mencaPelajaran Bahasa Indonesia indikator-indikator berikutnya yaitu siswa mampu menulis teks berita dengan memperhatikan keruntutan pemaparan, penggunaan kalimat, penggunakan kosakata, kemenarikan judul, dan penggunaan ejaan serta menulis teks berita dengan singkat, padat, dan jelas. Indikator tersebut belum dapat tercaPelajaran Bahasa Indonesia secara maksimal oleh siswa. Belum tercaPelajaran Bahasa Indonesianya indikator tersebut menyebabkan nilai rata-rata SMA Negeri 1 Pontianak masih berada dibawah kriteria ketuntasan minimal yang telah ditentukan yaitu 75 .

Penelitian ini menggunakan metode partisipatori dengan teknik ATTL. Metode dan teknik ini digunakan untuk mengetahui peningkatan dalam pembelajaran menulis teks berita. Metode pembelajaran partisipatori lebih menekankan keterlibatan siswa secara penuh. Siswa berkedudukan sebagai subjek belajar dan guru sebagai pemandu atau fasilitator. Aplikasi dari metode partisipatori yaitu dengan penggunaan teknik ATTL ini. Teknik ATTL ini merupakan teknik yang menggambarkan proses dalam mendapatkan berita mulai pengamatan mengenai objek berita samPelajaran Bahasa Indonesia dengan menghasilkan sebuah berita yang berupa teks berita.

Kegiatan tersebut mulai dari amati, tanya, tulis dan laporkan. Tahap A atau amati artinya siswa diajak untuk mengamati lingkungan. Lingkungan yang bisa dijadikan sumber pembelajaran tidak perlu yang jauh dari siswa. Siswa diberi kesempatan untuk keluar kelas dengan tujuan mengamati lingkungan dan mencari bahan yang dapat diijadikan sebagai berita. Pembelajaran langsung akan lebih mengesankan. Tahap $\mathrm{T}$ atau tanya adalah tahap yang dilakukan setelah tahap mengamati lingkungan. Tujuan tahap ini adalah menemukan hal atau informasi lain yang dapat dijadikan berita. Kegiatan ini dilakukan dengan berwawancara terhadap narasumber. Tahap yang ketiga adalah tahap tulis. Tahap ini adalah tahap inti dari proses pembelajaran. Tahap terakhir pada teknik ATTL adalah laporkan.

Pembelajaran ini siswa tidak hanya dituntut bisa menulis tetapi berani melaporkan hasil pekerjaannya di depan kelas. Penggunaan metode partisipatori dan teknik ATTL merupakan suatu proses pembelajaran yang menarik karena selama ini pembelajaran hanya bersifat teoretis tanpa adanya praktik. Selain kelebihan, metode partisipatori dan teknik ATTL juga memiliki kekurangan, yaitu siswa kurang tertib jika tidak diawasi. Mereka bisa menyalahgunakan waktu yang seharusnya untuk pengamatan digunakan untuk bermain. Untuk mencegah hal tersebut, guru harus bisa mengawasi semua peserta didik dan menyakinkan mereka bahwa pelajaran ini akan sangat bermanfaat jika mereka serius. Penggunaan metode partisipatori dengan teknik ATTL diharapkan dapat mempermudah siswa SMA Negeri 1 Pontianak dalam memahami teori dan dapat meningkatkan keterampilan menulis teks berita, serta mengubah perilaku siswa ke arah yang positif 


\section{METODE PENELITIAN}

Penelitian ini menggunakan metode penelitian tindakan kelas. Menurut Kammis (dalam Wiriaatmadja, 2009:12) meningkatkan penelitian tindakan adalah sebuah bentuk inkuiri reflektif yang dilakukan secara kemitraan mengenai situasi sosial tertentu (termasuk pendidikan) untuk meningkatkan rasionalitas dan keadilan dari a) Kegiatan praktek sosial atau pendidikan mereka, b) pemahaman mereka mengenai kegiatan-kegiatan praktek pendidikan ini, dan c) situasi yang memungkinkan terlaksananya kegiatan praktek ini. Menurut Oja dan Smulyan dalam Hasbulllah (2000:60) ada 4 (empat) bentuk Penelitian Tindakan Kelas (PTK) yaitu: 1) penelitian tindakan guru sebagai peneliti; 2) penelitian tindakan kolaboratif; 3) penelitian tindakan stimultan terintegrasi dan; 4) penelitian tindakan administrasi sosial eksperimental. Keempat bentuk Penelitian Tindakan Kelas (PTK) di atas ada persamaan dan perbedaannya menurut Oja dan Smulyan sebagaimana dikutip oleh Kasbollah (2000:60).

Sehubungan dengan beberapa bentuk Penelitian Tindakan Kelas (PTK) di atas, maka dalam hal ini peneliti menggunakan bentuk penelitian tindakan simultan terintegrasi. Menurut Hasbulllah (2000: 62) Penelitian tindakan simultan terintegrasi adalah salah satu bentuk penelitian tindakan yang bertujuan untuk dua hal sekaligus. Yaitu untuk memecahkan persoalan praktis dalam pembelajaran dan menghasilkan pengetahuan yang ilmiah dalam bidang pembelajaran di kelas. Dalam pelaksanaan tindakan yang sedemikian, guru dilibatkan dalam proses penelitian kelasnya, terutama pada aspek aksi dan refleksi terhadap permasalahan apa yang harus diteliti dalam kelasnya sendiri, terutama pada aspek aksi dan refleksi terhadap praktik-praktik pembelajaran di kelas. Dalam hal ini persoalan-persoalan pembelajaran yang diteliti muncul dan diidentifikasi oleh peneliti dari luar bukan guru atau guru yang bukan bersangkutan dengan mata pelajaran tersebut. Jadi, dalam bentuk ini guru bukan pencetus gagasan terhadap permasalahan apa yang harus diteliti dalam kelasnya sendiri. Dengan demikian, guru bukan inovator dalam penelitian ini tetapi sebaliknya yang mengambil posisi inovator adalah peneliti lain di luar guru. Penelitian ini menggunakan pendekatan kualitatif, yaitu peneliti berusaha mengungkapkan fakta-fakta atau mendeskripsikan tentang upaya peningkatan hasil belajar peserta didik pada aspek akhlak dengan metode demonstrasi dan bermain peran di Kelas XII IPS1 SMA Negeri 1 Pontianak.

Prosedur Penelitian Tindakan Kelas (PTK) dapat dilaksanakan melalui empat langkah utama yaitu: perencanaan (planning), pelaksanaan (acting), pengamatan (observing) dan refleksi (reflecting). Empat langkah utama dalam pelaksanaan Penelitan Tindakan Kelas (PTK) sering disebut dengan istilah satu siklus (Heldi. 2006:19). Untuk lebih jelas berikut ini dikemukakan model siklus Penelitian Tindakan Kelas (PTK): 


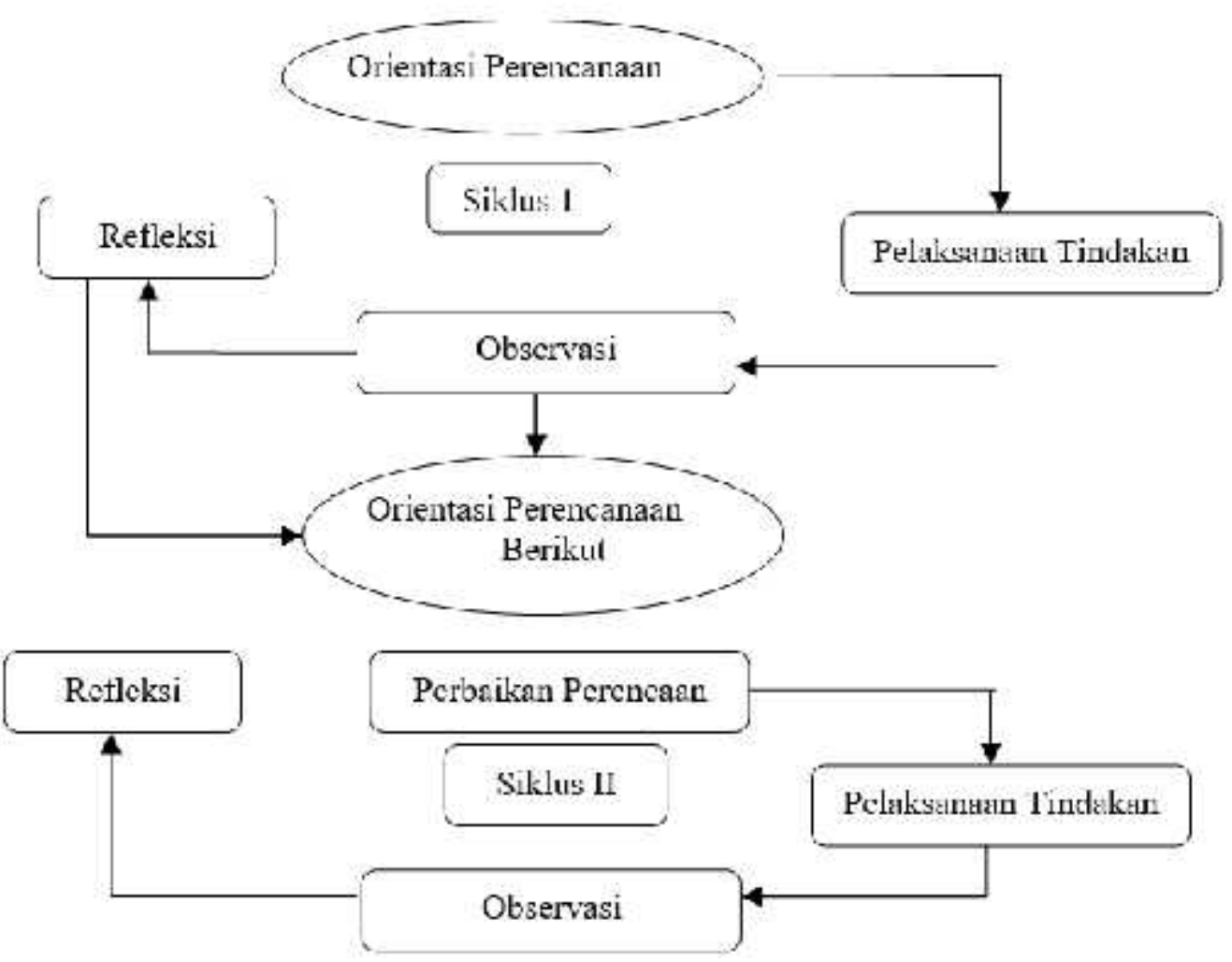

Gambar 1. Alur Penelitain PTK

\section{HASIL DAN PEMBAHASAN PENELITIAN}

\section{Hasil Penelitian Siklus I}

Hasil tes pada siklus I merupakan data awal diterapkannya pembelajaran keterampilan menulis teks berita menggunakan metode partisipatori dengan teknik ATTL. Secara umum, hasil tes kompetensi keterampilan menulis teks berita menggunakan metode partisipatori dengan teknik ATTL dapat dilihat pada tabel 1 berikut ini.

Tabel 1. Hasil Tes Keterampilan Menulis Teks Berita menggunakan Metode Partisipatori dengan Teknik ATTL Siklus I

\begin{tabular}{|c|c|c|c|c|c|c|c|}
\hline No & Kategori & $\begin{array}{c}\text { Rentang } \\
\text { Nilai }\end{array}$ & Frekuensi & Bobot & $\begin{array}{c}\text { Persentase } \\
(\%)\end{array}$ & Ratarata & $\begin{array}{c}\text { Ketuntasan } \\
(\%)\end{array}$ \\
\hline 1 & $\begin{array}{l}\text { Sangat } \\
\text { Baik }\end{array}$ & $88-100$ & 6 & 531 & 15,79 & \multirow{5}{*}{$\begin{array}{l}70,24 \\
\text { cukup }\end{array}$} & \multirow{5}{*}{$\begin{array}{c}(14: 38) \mathrm{x} \\
100= \\
36,84 \%\end{array}$} \\
\hline 2 & Baik & $75-87$ & 8 & 646 & 21,05 & & \\
\hline 3 & Cukup & $62-74$ & 15 & 955 & 39,47 & & \\
\hline \multirow[t]{2}{*}{4} & Kurang & $0-61$ & 9 & 537 & 23,69 & & \\
\hline & Jumlah & & 38 & 2669 & 100 & & \\
\hline
\end{tabular}

Data pada tabel 1 menunjukkan ketuntasan dalam kompetensi menulis teks berita menggunakan metode partisipatori dengan teknik ATTL. Tabel tersebut menunjukkan bahwa hasil tes kompetensi menulis teks berita siswa secara klasikal mencapai total nilai 2669 dengan rata-rata 70,24 dalam kategori cukup. Kelas XII IPS1 berjumlah 38 siswa, yang memperoleh nilai dalam kategori tuntas sebanyak 14 siswa.

Persentase ketuntasan sebesar 36,84\% Kelas XII IPS1 berjumlah 38 siswa, yang memperoleh nilai dalam kategori sangat baik dengan rentang nilai 88-100 ada 6 siswa atau $15,79 \%$, kategori baik sebanyak 8 siswa atau sebesar $21,05 \%$ dengan rentang nilai $75-87$, kategori cukup sebanyak 15 siswa atau sebesar 39,47\% dengan rentang nilai 62-74, dan kategori kurang sebanyak 9 siswa atau sebesar 23,69\% dengan rentang nilai 0-61. 
Hasil tes yang didapatkan dari siklus I masih kurang memuaskan. Masih terdapat 9 siswa yang mempunyai nilai tes dalam kategori kurang. Rendahnya nilai siswa dalam tes menulis teks berita karena pembelajaran menulis teks berita menggunakan metode partisipatori dengan teknik ATTL masih dirasakan baru oleh siswa. Proses pembelajaran seperti ini merupakan proses awal bagi siswa untuk menyesuaikan diri dalam belajar. Oleh karena itu, perlu diadakan tes lagi pada siklus II supaya hasilnya lebih baik. Untuk mengetahui nilai yang diperoleh siswa maka dipaparkan grafik nilai tes siklus I. Aspek Kelengkapan Unsur Berita (mengandung $5 \mathrm{~W}+1 \mathrm{H}$ ) Hasil tes kelengkapan unsur berita pada siklus I dapat dilihat pada tabel 2 berikut.

Tabel 2. Hasil Penilaian Aspek Kelengkapan Unsur Berita

\begin{tabular}{|c|c|l|c|c|c|c|c|c|}
\hline No & Kategori & \multicolumn{1}{|c|}{ Kreteria } & Skor & F & Bobot & $\begin{array}{c}\text { Persentase } \\
(\%)\end{array}$ & Rata-rata & $\begin{array}{c}\text { Ketuntasan } \\
(\%)\end{array}$ \\
\hline 1 & $\begin{array}{c}\text { Sangat } \\
\text { Baik }\end{array}$ & $\begin{array}{l}\text { Lengkap, terdapat 6 } \\
\text { unsur }\end{array}$ & 30 & 11 & 330 & 28,95 & & \\
\hline 2 & Baik & $\begin{array}{l}\text { Cukup lengkap, terdapat } \\
\text { 5 unsur }\end{array}$ & 25 & 17 & 425 & 44,73 & & \\
\hline 3 & Cukup & $\begin{array}{l}\text { Kurang Lengkap, } \\
\text { Erdapat 4 unsur }\end{array}$ & 15 & 9 & 135 & 23,69 & $\begin{array}{c}900: 38 \\
=23,6 \\
\text { kategor } \\
\text { i cukup }\end{array}$ & $\begin{array}{c}(28: 38) \mathrm{x} \\
100 \\
=73,68 \%\end{array}$ \\
\hline 4 & Kurang & $\begin{array}{l}\text { Tidak lengkap, kurang } \\
\text { dari 4 unsur }\end{array}$ & 10 & 1 & 10 & 2,63 & \\
\hline & Jumlah & & 38 & 900 & & 100 & & \\
\hline
\end{tabular}

Data pada tabel 2 menunjukkan peningkatan rata-rata skor pada aspek kelengkapan unsur berita pada siklus I secara klasikal mencapai total nilai 900 dengan rata-rata 23,6 dalam kategori cukup. Ketuntasan siswa sebesar 73,68\%. Kelas XII IPS1 berjumlah 38 siswa, yang memperoleh nilai dalam kategori sangat baik dengan skor 30 ada 11 siswa atau $28,95 \%$, kategori baik sebanyak 17 siswa atau sebesar 44,73\% dengan skor 30, kategori cukup sebanyak 9 siswa atau sebesar 23,69\% dengan skor 15, dan kategori kurang sebanyak 1 siswa atau sebesar 2,63\% dengan skor 10 .

\section{Hasil Penelitian Siklus II}

Pembelajaran keterampilan menulis teks berita pada siklus II ini merupakan perbaikan dan pemecahan masalah yang dihadapi pada siklus I. Pada siklus II ini diuraikan tentang pelaksanaan pembelajaran menulis teks berita menggunakan metode partisipatori dengan teknik ATTL terdiri atas data tes dan data nontes. Hasil Tes Keterampilan Menulis Teks Berita Siklus II Hasil keterampilan menulis teks berita menggunakan metode partisipatori dengan teknik ATTL pada siklus II dapat dilihat pada tabel berikut.

Tabel 3. Hasil Tes Keterampilan Menulis Teks Berita Siklus II

\begin{tabular}{|c|c|c|c|c|c|c|c|}
\hline No & Kategori & $\begin{array}{c}\text { Rentang } \\
\text { Nilai }\end{array}$ & Frekuensi & Bobot & $\begin{array}{c}\text { Persentase } \\
(\%)\end{array}$ & Ratarata & $\begin{array}{c}\text { Ketuntasan } \\
(\%)\end{array}$ \\
\hline 1 & Sangat Baik & $88-100$ & 17 & 1547 & 44,74 & \multirow{5}{*}{$\begin{array}{l}84,81 \\
\text { (baik) }\end{array}$} & \multirow{5}{*}{$\begin{array}{c}37: 38= \\
97,36 \%\end{array}$} \\
\hline 2 & Baik & $75-87$ & 20 & 1603 & 52,63 & & \\
\hline 3 & Cukup & $62-74$ & 1 & 73 & 2,63 & & \\
\hline 4 & Kurang & $0-61$ & - & - & - & & \\
\hline & Jumlah & & 38 & 3223 & 100 & & \\
\hline
\end{tabular}


Data pada tabel 3 menunjukkan ketuntasan hasil belajar siswa dalam keterampilan menulis teks berita menggunakan metode partisipatori dengan teknik ATTL. Ketuntasan pada siklus II meningkat dibandingkan siklus I. Tabel 10 menunjukkan ketuntasan siswa mencapai $97,36 \%$. Sejumlah 37 siwa sudah mencapai batas minimal. 70 Rata-rata skor pada siklus II ini menunjukkan peningkatan dibandingkan rata-rata skor pada siklus I.

Tabel tersebut menunjukkan bahwa hasil tes kompetensi menulis teks berita siswa secara klasikal mencapai total nilai 3223 dengan rata-rata 84,81 dengan kategori baik. Kelas XII IPS1 berjumlah 38 siswa, yang memperoleh nilai dalam kategori sangat baik dengan rentang nilai 88-100 ada 17 siswa. Kategori baik sebanyak 20 siswa dengan rentang nilai 75-88. Kategori cukup sebanyak 1 siswa dengan rentang nilai 62-74. Hasil tersebut sudah sesuai dengan target yang diharapkan peneliti. Maka, penelitian pada siklus II ini dinyatakan berhasil, karena sesuai dengan tujuan penelitian, yaitu siswa mengalami peningkatan keterampilan menulis teks berita dengan pencapaian skor berkategori baik.

Di bawah ini adalah tabel hasil tes keterampilan siswa dalam aspek kelengkapan unsur berita (mengandung unsur $5 \mathrm{~W}+1 \mathrm{H}$ ).

Tabel 4. Hasil Penilaian Aspek Kelengkapan Unsur Berita

\begin{tabular}{|c|c|c|c|c|c|c|c|c|}
\hline No & Kategori & Kreteria & Skor & $\mathrm{F}$ & Bobot & $\begin{array}{c}\text { Persentase } \\
(\%)\end{array}$ & Rata-rata & $\begin{array}{c}\text { Ketuntasan } \\
(\%)\end{array}$ \\
\hline 1 & $\begin{array}{l}\text { Sangat } \\
\text { Baik }\end{array}$ & $\begin{array}{c}\text { Lengkap, terdapat } \\
6 \text { unsur } 30381140 \\
100\end{array}$ & 30 & 38 & 1140 & 100 & \multirow{5}{*}{$\begin{array}{c}1140: 38= \\
30 \text { sangat } \\
\text { baik }\end{array}$} & \multirow{5}{*}{$\begin{array}{c}(38: 38) X \\
100= \\
100 \%\end{array}$} \\
\hline 2 & Baik & $\begin{array}{l}\text { Cukup lengkap, } \\
\text { terdapat } 5 \text { unsur }\end{array}$ & 25 & - & - & - & & \\
\hline 3 & Cukup & $\begin{array}{l}\text { Kurang Lengkap, } \\
\text { terdapat } 4 \text { unsur }\end{array}$ & 15 & - & - & - & & \\
\hline 4 & Kurang & $\begin{array}{l}\text { Tidak lengkap, } \\
\text { kurang dari } 4 \text { unsur }\end{array}$ & 10 & - & - & - & & \\
\hline & Jumlah & & & 38 & 1140 & 100 & & \\
\hline
\end{tabular}

Data pada tabel 4 menunjukkan peningkatan rata-rata skor pada aspek kelengkapan teks berita pada siklus II secara klasikal mencapai total nilai 1140 dengan rata-rata 30 dalam kategori sangat baik. Kelas XII IPS1 yang berjumlah 38 siswa memperoleh nilai dalam kategori sangat baik dengan skor 30. Ketuntasan siswa pada aspek ini mencapai $100 \%$ artinya $100 \%$ siswa mampu menulis berita dengan unsur yang lengkap. Hasil ini menunjukan peningkatan yang signifikan.

Perolehan hasil tes peningkatan keterampilan menulis teks berita pada siklus I dan siklus II siswa Kelas XII IPS1 SMA Negeri 1 Pontianak. Ketuntasan nilai siswa pada siklus 1 sebesar 36,84\%, sedangkan ketuntasan pada siklus 2 sebesar 97,36\%. Berdasarkan hasil tersebut diketahui bahwa ketuntasan nilai siswa meningkat sebesar $60,52 \%$. Pada siklus I terdapat 14 siswa yang tuntas dalam pembelajaran, sedangkan pada siklus II siswa yang tuntas sebanyak 37 siswa. Peningkatan ketuntasan hasil tes kompetensi pada siklus I dan siklus II. Nilai rata-rata siswa pada siklus I sampai dengan siklus II mengalami peningkatan. Pada tes siklus I ketuntasan siswa sebesar 36,84\%, sedangkan pada siklus II sebesar 97,36\%. Pada hasil rata-rata kelas juga mengalami peningkatan. Hal ini menunjukkan hasil tes yang dicapai pada siklus II mengalami peningkatan sebesar $60,52 \%$ dari hasil siklus I. Pada tes siklus I nilai rata-rata kelas sebesar 70,24 atau dalam kategori baik dengan rentang nilai 75-87, sedangkan pada siklus II hasil tes menjadi 84,61 dalam kategori baik dengan rentang nilai 75-87.

Hal ini menunjukkan hasil ratarata yang dicapai pada siklus II mengalami peningkatan sebesar 14,57 dari hasil siklus I. Pada siklus I siswa yang mencapai batas KKM sejumlah 14 siswa dengan rentang 75-87 atau dalam kategori baik. Kendala yang dihadapi siswa adalah siswa masing malu-malu untuk melakukan wawancara dengan 
narasumber. Setelah pelaksanaan tes menulis teks berita pada siklus I dengan nilai rata-rata 70,24 atau dalam kategori baik. Siklus I masih belum mencapai nilai rata-rata batas minimal, yaitu 75, sehingga hasil tersebut perlu ditingkatkan lagi pada siklus II. Perolehan ketuntasan tiap aspek pada siklus I dan siklus II beserta perbandingan dan peningkatannya disajikan.

Berdasarkan rekapitulasi data hasil tes kompetensi menulis teks berita dari siklus I sampai dengan siklus II, sebagaimana tersaji dalam tabel di atas, dapat dijelaskan bahwa kompetensi menulis teks berita pada tiap aspek penilaian mengalami peningkatan. Untuk mengetahui peningkatan tahap tersebut maka diuraikan menjadi perbandingan nilai tiap aspek kompetensi menulis teks berita pada siklus I dan siklus II.

Dari tabel 20 dapat dijelaskan perolehan ketuntasan masing-masing aspek penilaian. Aspek kelengkapan unsur berita pada siklus I sebesar 73,68\% dan pada siklus II sebesar $100 \%$. Aspek keruntutan pemaparan pada siklus I sebesar 71,05\% dan pada siklus II sebesar $100 \%$. Aspek penggunaaan kalimat pada siklus I sebesar $65,78 \%$ dan pada siklus II sebesar 12,76. Aspek penggunaan kosakata pada siklus I sebesar $86,84 \%$ dan pada siklus II sebesar $100 \%$. Aspek kemenarikan judul pada siklus I sebesar $86,84 \%$ dan pada siklus II sebesar $89,47 \%$. Aspek ketepatan penggunaan ejaaan pada siklus I sebesar $29,94 \%$ dan pada siklus II sebesar $44,73 \%$.

Peningkatan keterampilan menulis teks berita merupakan prestasi yang membanggakan. Sebelum dilakukan tindakan siklus I dan siklus II, keterampilan menulis teks berita siswa masih berada dibawah KKM. Setelah dilakukan tindakan siklus I dan siklus II, hasil menulis teks berita siswa menjadi lebih baik. Hal tersebut terjadi karena siswa sudah dapat memahami dengan baik langkahlangkah yang harus dilakukan untuk menulis tesk berita. Pada siklus II, siswa juga merasa senang dengan penggunaan metode partisipatori dengan teknik ATTL dalam pembelajaran. Alasan siswa karena menurut mereka penggunaan metode partisipatori dengan teknik ATTL dapat meningkatkan keaktifan mereka dalam berdiskusi dan dapat mempermudah mereka dalam menulis teks berita karena berhubungan langsung dengan lingkungan dan narasumber.

Perubahan Perilaku Siswa setelah Mengikuti Pembelajaran Menulis Teks Berita menggunakan Metode Partisipatori dengan Teknik ATTL Hasil penelitian menunjukkan bahwa peningkatan kemampuan menulis teks berita diikuti pula dengan perubahan perilaku siswa. Perilaku tersebut, yaitu kesiapan siswa dalam mengikuti pembelajaran, perhatian dan sikap siswa (antusiasme) pada saat mendapat penjelasan dari guru, keaktifan siswa dalam melakukan diskusi, kesungguhan siswa dalam mengerjakan tugas yang diberikan guru, tanggung jawab siswa dalam mengumpulkan tugas, dan partisipasi siswa pada saat refleksi.

Perubahan perilaku ke arah yang positif terjadi setelah diterapkan pembelajaran menulis teks berita menggunakan metode partisipatori dengan teknik ATTL. Perubahan perilaku siswa dapat diidentifikasi dari hasil observasi, wawancara, dan dokumentasi foto. Perubahan tingkah laku siswa selama pembelajaran pada siklus I dan siklus II yang diperoleh dari hasil pengamatan atau observasi selama proses pembelajaran berlangsung.

Rekapitulasi data hasil nontes diatas dari siklus I sampai dengan siklus II, sebagaimana tersaji dalam tabel di atas, dapat dijelaskan bahwa perilaku siswa mengalami peningkatan. Untuk mengetahui peningkatan tahap tersebut maka diuraikan menjadi perbandingan nilai tiap perilaku yang diamati pada siklus I dan siklus II. Dari tabel 21 dapat dijelaskan perolehan masing-masing perilaku. Aspek kesiapan siswa dalam mengikuti pembelajaran pada siklus I sebesar $63,15 \%$, pada siklus II sebesar $92,11 \%$. perhatian dan sikap siswa pada saat mendapat penjelasan dari guru pada siklus I sebesar $63,15 \%$, pada siklus II sebesar $100 \%$. keaktifan siswa dalam melakukan diskusi pada siklus I sebesar $23,68 \%$, pada siklus II sebesar $63,16 \%$, kesungguhan siswa dalam mengerjakan tugas yang diberikan guru pada siklus I sebesar 65,79\%, pada siklus II sebesar $100 \%$, 
Tanggung jawab siswa dalam mengumpulkan tugas pada siklus I sebesar 100\%, pada siklus II sebesar $100 \%$, dan partisipasi siswa pada saat refleksi siklus I sebesar $31,58 \%$, pada siklus II sebesar $63,16 \%$. Perubahan perilaku siswa juga dapat dilihat dari hasil wawancara. Berdasarkan hasil wawancara diketahui bahwa kesiapan siswa, perhatian, dan kesungguhan siswa mengalami perubahan ke arah positif. Semua siswa yang diwawancara merasa senang dan antusias dalam mengikuti setiap langkah pembelajaran. Pada siklus II siswa lebih memperhatikan dan mengikuti dengan baik setiap perintahperintah yang diberikan oleh guru. Perubahan sikap siswa dalam mendengarkan penjelasan guru, melakukan diskusi, dan mengerjakan tugas juga terlihat dari hasil dokumentasi foto. Gambar 7 pada lampiran merupakan perubahan perilaku siswa pada saat mendengarkan penjelasan guru.

\section{KESIMPULAN}

Berdasarkan hasil penelitian dan pembahasan, dapat disimpulkan bahwa hasil penelitian ini menunjukkan adanya peningkatan keterampilan menulis teks berita menggunakan metode partisipatori dengan teknik ATTL. Hasil ketuntasan tes pada siklus I sebesar 36,84\% dengan nilai rata-rata kelas sebesar 70,24 dalam kategori baik. Pada siklus II, hasil ketuntasan siswa sebesar 97,36\% dengan nilai rata-rata sebesar 84,81 dan termasuk dalam kategori baik. Dengan demikian, terjadi peningkatan ketuntasan sebesar $60,52 \%$ dari hasil siklus I. Hasil yang dicapai pada siklus II tersebut sudah melebihi target ketuntasan yang telah ditetapkan, yaitu 75. Hasil tes tersebut menunjukkan bahwa setelah dilakukan penelitian menulis teks berita menggunakan metode partisipatori dengan teknik ATTL, kemampuan siswa dalam menulis teks berita meningkat. Hasil penelitian ini menunjukkan adanya perubahan perilaku siswa Kelas XII IPS1 SMA Negeri 1 Pontianak ke arah yang positif. Hal tersebut terlihat dari sikap siswa yang antusias dan lebih tertarik dan bersemangat dalam mengikuti kegiatan pembelajaran. Siswa tampak lebih aktif dan tidak malu bertanya pada narasumber dan ketika menemui kesulitan. Siswa juga lebih siap menerima pelajaran. Hal tersebut dapat diketahui dari hasil nontes yang meliputi hasil observasi, wawancara, dan dokumentasi foto pada siklus I dan siklus II.

\section{SARAN}

1. Sebaiknya guru menerapkan metode partisipatori dengan teknik ATTL dalam proses pembelajaran Pelajaran Bahasa Indonesia khususnya pada keterampilan menulis teks berita.

2. Diharapkan bagi guru mata pelajaran lain dapat mengadakan penelitian tindakan kelas yang berhubungan dengan peningkatan hasil belajar dan aktivitas peserta didik dalam proses belajar mengajar dengan metode partisipatori dengan teknik ATTL

3. Apabila guru ingin menerapkan sistem pembelajaran metode partisipatori dengan teknik ATTL hendaknya mempersiapkan segala sesutu yang berkaitan dengan pelaksanaannya di dalam proses pembelajaran.

4. Bila ingin memperoleh pembelajaran yang menyenangkan, hasil yang baik serta aktivitas yang tidak membosankan maka terapkan strategi-strategi atau metode pembelajaran yang cocok atau sesuai dengan materi

\section{DAFTAR PUSTAKA}

Hasbulllah, 2000. Dasar-Dasar Ilmu Pendidikan. Jakarta: PT Raja Grafindo Persada.

Heldi. 2006. Metode Penelitian Pendidikan. Ciputat: Quantum Teaching,

Subyantoro. 2008. Dasar-Dasar Keterampilan Menulis. Semarang: Cipta Prima Nusantara Tarigan, Azhari Akmal, Dkk, 2009. Menjaga Tradisi Mengenal Modernitas Apresiasi Terhadap Pemikiran dan Kiprah Lahmuddin Nasution Bandung: Citapustaka Media Perintis.

Wagiran dan Mukh Doyin. 2005. Curah Gagasan. Semarang: Rumah Indonesia. 
Prastowo, A. (2015). Panduan Kreatif Membuat Bahan Ajar Inovatif. Yogyakarta: Diva Press.

Ratumanan, T., \& Laurens, T. (2011). Penilaian Hasil Belajar pada Tingkat Satuan Pendidikan. Surabaya: Unesa University Press. 